\title{
Last-century forest productivity in a managed dry-edge Scots pine population: the two sides of climate warming
}

\author{
Laura Marqués, ${ }^{1,5}$ Jaime Madrigal-González, ${ }^{1}$ Miguel A. Zavala, ${ }^{1}$ Jesús Julio Camarero, $^{2}$ and Florian Hartig ${ }^{3,4}$ \\ ${ }^{1}$ Forest Ecology and Restoration Group, Department of Life Sciences, Universidad de Alcalá, Campus Universitario, \\ Alcalá de Henares 28871 Spain \\ ${ }^{2}$ Instituto Pirenaico de Ecología (IPE-CSIC), Avenida Montañana, 1005, Zaragoza 50192 Spain \\ ${ }^{3}$ Biometry and Environmental System Analysis, University of Freiburg, Tennenbacherstrasse 4, Freiburg 79106 Germany \\ ${ }^{4}$ Theoretical Ecology, Faculty of Biology and Pre-Clinical Medicine, University of Regensburg, Universitätsstraße 3, \\ Regensburg 93053 Germany
}

\begin{abstract}
Climate change in the Mediterranean, associated with warmer temperatures and more frequent droughts, is expected to impact forest productivity and the functioning of forests ecosystems as carbon reservoirs in the region. Climate warming can positively affect forest growth by extending the growing season, whereas increasing summer drought generally reduces forest productivity and may cause growth decline, trigger dieback, hamper regeneration, and increase mortality. Forest management could potentially counteract such negative effects by reducing stand density and thereby competition for water. The effectiveness of such interventions, however, has so far mostly been evaluated for short time periods at the tree and stand levels, which limits our confidence regarding the efficacy of thinning interventions over longer time scales under the complex interplay between climate, stand structure, and forest management. In this study, we use a century-long historical data set to assess the effects of climate and management on forest productivity. We consider rear-edge Scots pine (Pinus sylvestris) populations covering continental and Mediterranean conditions along an altitudinal gradient in Central Spain. We use linear mixed-effects models to disentangle the effects of altitude, climate, and stand volume on forest growth and ingrowth (recruitment and young trees' growth). We find that warming tends to benefit these tree populations, warmer winter temperature has a significant positive effect on both forest growth and ingrowth, and the effect is more pronounced at low elevations. However, drought conditions severely reduce growth and ingrowth, in particular when competition (stand volume) is high. We conclude that summer droughts are the main threat to Scots pine populations in the region, and that a reduction of stand volume can partially mitigate the negative impacts of more arid conditions. Mitigation and adaptation measures could therefore manage stand structure to adopt for the anticipated impacts of climate change in Mediterranean forest ecosystems.
\end{abstract}

Key words: competition; drought stress; rear-edge; Scots pine; shelterwood management; stand volume; summer water deficit.

\section{INTRODUCTION}

Forest ecosystems are of global importance as carbon reservoirs (Pan et al. 2011) and as providers of ecosystem services (Millennium Ecosystem Assessment 2005). The future of many of these key ecosystem services, however, is in peril, due to imminent climate change (Anderegg et al. 2013, Nabuurs et al. 2013). Arguably, the two most important climatic constraints in seasonal biomes are low winter temperatures and reduced water availability in summer or the respective dry period (Churkina and Running 1998). Low winter temperatures limit growth by shortening the growing season, reducing meristem activity, and indirectly by depressing photosynthetic rates (Körner 2015). Water deficit reduces forest productivity and growth, and can in extreme cases lead to dieback

Manuscript received 3 May 2017; revised 31 July 2017; accepted 23 August 2017. Corresponding Editor: Emil Cienciala.

${ }^{5}$ E-mail: laura.marques@edu.uah.es episodes due to heat stress and dry spells (VicenteSerrano et al. 2013, Anderegg et al. 2015). As climate change is expected to modify both winter temperature and water availability, it may have major impacts on forest ecosystems (Binkley et al. 2004, Schulze et al. 2005). The nature of this impact, however, is highly dependent on the balance of the limiting factors present at a particular site (Boisvenue and Running 2006). Rising temperatures could amplify drought frequency and severity, resulting in a decline of forest productivity in drought-prone areas (Allen et al. 2010). On the other hand, an extended growing season may benefit forest growth, as observed in alpine areas of Central Europe (Pretzsch et al. 2014). Moreover, these reactions can be modified by stand structure and management (Frelich 2002). Only when considering all processes together can we expect to correctly understand how forests respond to climate change.

One of the ecosystems most vulnerable to climate warming is the Mediterranean Basin (Schröter et al. 
2005). Predictions agree that rising temperature and more severe heat waves and dry spells will occur in this region in the future (see, e.g., Nogués Bravo et al. 2008 for the period of 2070-2099), potentially reducing forest growth and increasing tree mortality (Galiano et al. 2010, Camarero et al. 2015b). The terrestrial carbon sequestration in Mediterranean forests currently ranges between $0.01-1.08 \mathrm{Mg} \cdot \mathrm{ha}^{-1} \cdot \mathrm{yr}^{-1}$ (Croitoru and Merlo 2005). Climate change threatens this important ecosystem service provided by Mediterranean water-limited forest (Fischlin et al. 2007, Vayreda et al. 2012). The combination of warm and dry periods makes the summer a particularly critical moment for the performance of Mediterranean tree species (Peñuelas et al. 2011, Galván et al. 2014). This is especially true for tree populations forming the species southernmost distribution limit (rear edge), subjected to xeric conditions, whose growth and recruitment dynamics are often hampered by water shortage (Hampe and Petit 2005, Benavides et al. 2016, Marqués et al. 2016). On the other hand, the same species may face continental Mediterranean conditions in inland regions, where dry summers, but also cold winters, constrain forest growth and affect tree performance and survival (Herguido et al. 2016). In Mediterranean mountain areas, forest growth responses to climate change drastically along altitudinal gradients (Candel-Pérez et al. 2012, Sánchez-Salguero et al. 2015a). Warmer winter temperatures may have a positive effect on forest productivity by extending the growing season (Menzel and Fabian 1999, Peñuelas and Filella 2001), particularly at higher elevations (Wullschleger et al. 2002). However, climate change might also alter hardening processes, making trees more vulnerable to frost damage including xylem embolism caused by freeze-thaw cycles (Camarero et al. 2015a).

The dependence of tree performance on climate can be modified by forest management. In recent years, much attention has been devoted to better understanding the interplay between these two factors, in particular for developing mitigation and adaptation options to address climate change impacts on forest productivity and carbon stocks (Klein et al. 2007, IPCC 2014). Looking at adaptation options for reducing the effect of climate change, modifying stand density has attracted particular interest (Spiecker 1999). Competition has been shown to modulate forest productivity and stand growth responses to climate (Magruder et al. 2013). Individual size and tree population density may aggravate the negative impacts of drought on forest productivity in drought-prone areas as the Mediterranean Basin (Sánchez-Salguero et al. 2012, Ruiz-Benito et al. 2013). Studies suggest that thinning will benefit trees through reduced competition for space and higher water uptake (Martín-Benito et al. 2010, Giuggiola et al. 2013, Sohn et al. 2016). Adaptation through managing the amount and distribution of individual trees in a stand is therefore a promising tool to maintain population stability (Keenan 2012) and to preserve future carbon reservoirs.
Many previous studies that examined the interaction of forest management and climatic factors are based on experiments (Pretzsch 2009) and retrospective approaches such as dendrochronology (Camarero et al. 2011). The experimental approaches are typically limited in temporal and spatial scale, and results may therefore not extrapolate to long-term forest productivity (Rees et al. 2001). Tree-ring growth studies encompass wide spatial and temporal scales, but often lack information on past management legacies, potentially creating biased assessments of changes in tree growth (Bowman et al. 2013). In addition, the relationship between stand productivity and individual tree growth is often complicated, since plasticity, competition, and tree mortality may modify the scaling from tree to stand-level variables (Pretzsch and Biber 2005). Information on long-term forest productivity at landscape level hence remains scarce. Therefore, existing longterm forestry data sets are a unique and valuable alternative source of information on climate-management interactions in forests (e.g., Pretzsch 2006, Madrigal-González and Zavala 2014, Madrigal-González et al. 2015), especially when they are aligned across altitudinal gradients, which allow estimating the responses of otherwise relatively similar forests to climatic variation and management.

In this study, we use such a historical long-term data set with $113 \mathrm{yr}$ of forest information recorded at decadal resolution in a continental Mediterranean Scots pine (Pinus sylvestris) forest situated in Central Spain along a 900-m ample altitudinal gradient. We evaluate how climatic drivers and management have influenced forest productivity over the last century. Specifically, we ask (1) What was the effect of known climatic stressors (winter coldness and summer drought) on forest productivity? (2) How does forest productivity response to climate warming across the altitudinal gradient? (3) To what extent did historical management practices modulate these responses and what potential does thus exist for management to buffer climate change impacts? We considered two components of forest productivity: forest growth, which is estimated as the stand volume of adult trees, and forest ingrowth, corresponding to growth of dominated individuals reaching the canopy. We hypothesize that (1) warm winter temperatures and cool and wet summer conditions enhance forest productivity; (2) forest responses to climate vary along the altitudinal gradient, with larger temperature sensitivity toward higher elevations and larger drought stress toward lower elevations; and (3) forest responses to climate depend on management, specifically that lower stand volume reduces the vulnerability to drought stress.

\section{Material And Methods}

\section{Study area}

The study was carried out in the Guadarrama mountain range (latitude $40^{\circ} 58^{\prime}-41^{\circ} 03^{\prime} \mathrm{N}$, longitude $3^{\circ} 46^{\prime}-$ $3^{\circ} 52^{\prime} \mathrm{W}$, central Spain), in a managed pine forest 
(named Pinar de Navafría and corresponding to M.U.P. 198 in the catalog of public forests of the province of Segovia). The site covers an area of 2,760 ha, distributed along an altitudinal gradient from 1,300 to $2,000 \mathrm{~m}$ above sea level (a.s.l., Fig. 1).

The climate in the area is continental Mediterranean, with cold winters and warm dry summer seasons (Kottek et al. 2006). Mean annual temperature varies from $10.3^{\circ}$ to $6.5^{\circ} \mathrm{C}$ and total annual rainfall from 510 to $1223 \mathrm{~mm}$, upward with the elevation gradient (values obtained from two meteorological stations: Granja de San Ildefonso $40^{\circ} 46^{\prime} \mathrm{N}, 4^{\circ} 00^{\prime} \mathrm{W}$, at $1191 \mathrm{~m}$ a.s.1., $23 \mathrm{~km}$, and Puerto de Navacerrada, $40^{\circ} 47^{\prime} \mathrm{N}, 4^{\circ} 00^{\prime} \mathrm{W}$, at $1894 \mathrm{~m}$ a.s.1., $33 \mathrm{~km}$; data provided by the Spanish Meteorological Agency, AEMET).

The dominant species in the area is Scots pine (Pinus sylvestris L.), co-occurring with Pyrenean oak (Quercus pyrenaica Willd.) and shrubs (Cistus laurifolius L., Cytisus scoparius (L.) Link). In the highlands, Scots pine and common juniper (Juniperus communis L.) are present. The understory is generally weakly developed. Sedimentary substrates form sand soils and have low potential storage of organic carbon.

Scots pine is one of the most widespread conifer species. It reaches its southern and dry distributions limits in the Iberian Peninsula (Barbero et al. 1998). Scots pine is one of the more drought-vulnerable pine species occurring in southern Europe, and several droughtinduced dieback episodes characterized by growth decline and increased mortality of recruits have been described in response to dry spells, particularly near the species rear edge (Martínez-Vilalta and Piñol 2002, Eilmann and Rigling 2012, Herrero et al. 2013, Camarero et al. 2015b, Galván et al. 2015). Notably, also winter drought and sharp drops in air temperature have been also identified as drivers of forest dieback in rear-edge Scots pine populations subjected to continental Mediterranean conditions (Camarero et al. 2015a).

\section{Forest data: growth and ingrowth measurements}

To study forest dynamics in the area, we digitized data from historical forest management archives. These plans contain forestry information reviewed every $10 \mathrm{yr}$ since 1896, until its last update in 2008. With over a century, this is an exceptionally long time series. At stand level, the data includes height, diameter at breast height (dbh, measured at $1.3 \mathrm{~m}$ ), stand volume, stand density, and thinning practices (Appendix S1: Table S1). In the historic data, the forest had been subdivided into nine
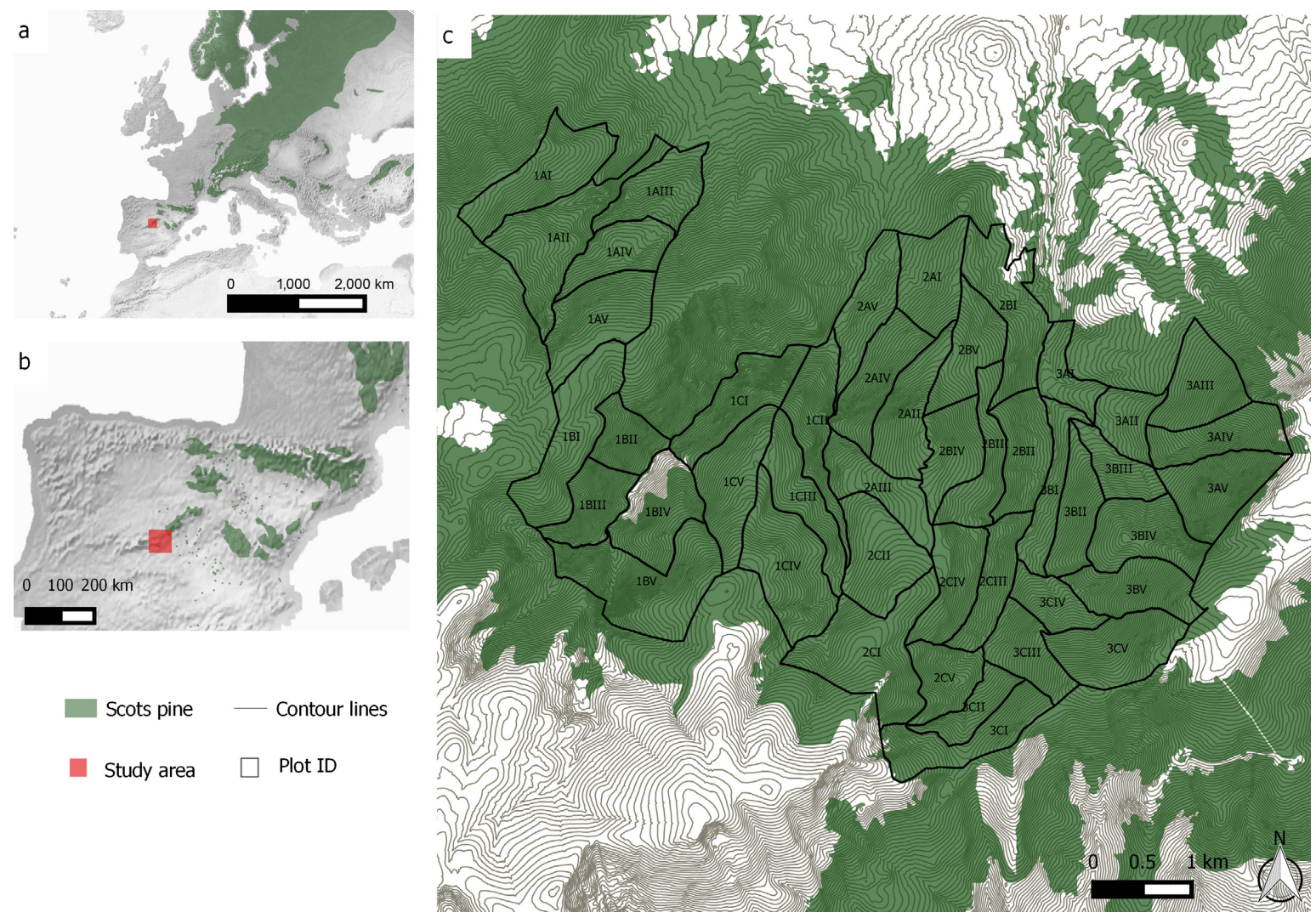

FIG. 1. (a) Distribution of Scots pine forests in Europe and (b) geographical situation of the study area in central Spain. (c) Map of the study site in the Guadarrama range (Segovia, central Spain). Solid black lines show the forest division into 45 experimental units. 
subunits (named cuarteles in Spanish; 305 ha mean size), and each of these subunits was further partitioned into five stands (named tramos in Spanish; 61 ha mean size), resulting in 45 experimental units (see solid lines in Fig. 1c). For each of those, forest management was based on shelterwood cutting applied in permanent plots (Smith et al. 1997) in order to maintain an uneven-aged forest canopy and provide natural regeneration with moderate thinning over a 100 -yr rotation period.

A number of representative trees belonging to different dbh classes (20-29, 30-39, 40-49, 50-59, 60-69, $>70 \mathrm{~cm}$ ) were harvested every decade by forest technicians. From these selected trees, the trunk was subdivided into smaller pieces and the stand volume was calculated by applying a cylinder equation. Stand density $\left(N_{2}\right)$ in each stand was assessed by counting all the individuals. Stand volume $\left(V_{2}\right)$ was calculated from dbh and height measurements of each tree considering allometric coefficients estimated from the harvested trees. Management applied during the years was recorded in volume $\left(V_{t}\right)$ and density $\left(N_{t}\right)$ of harvested trees. Previous stand volume $\left(V_{1}\right)$ was used as a proxy of competition in the stands.

We defined forest growth $(G)$ as the increase adult trees wood volume $\left(\mathrm{m}^{3} / \mathrm{ha}\right)$. Forest ingrowth $(I)$ was defined as the number of new individuals larger than $20 \mathrm{~cm}$ diameter at breast height (dbh), i.e., as an integrated measure of recruitment and young trees' (poles) growth (individuals/ha). Both values were estimated for each 10-yr time interval from the difference in volume and individuals respectively, considering the thinning carried out during the decade (Fig. 2a, b):

$$
\begin{aligned}
& G=\Delta V=V_{2}-V_{1}+V_{t} \\
& I=\Delta N=N_{2}-N_{1}+N_{t}
\end{aligned}
$$

In the equations, $V_{2}$ is the stand volume at the time $t$, $V_{1}$ is the stand volume at the time $t-10$, and $V_{t}$ is the harvested stand volume in the period of $10 \mathrm{yr}$.
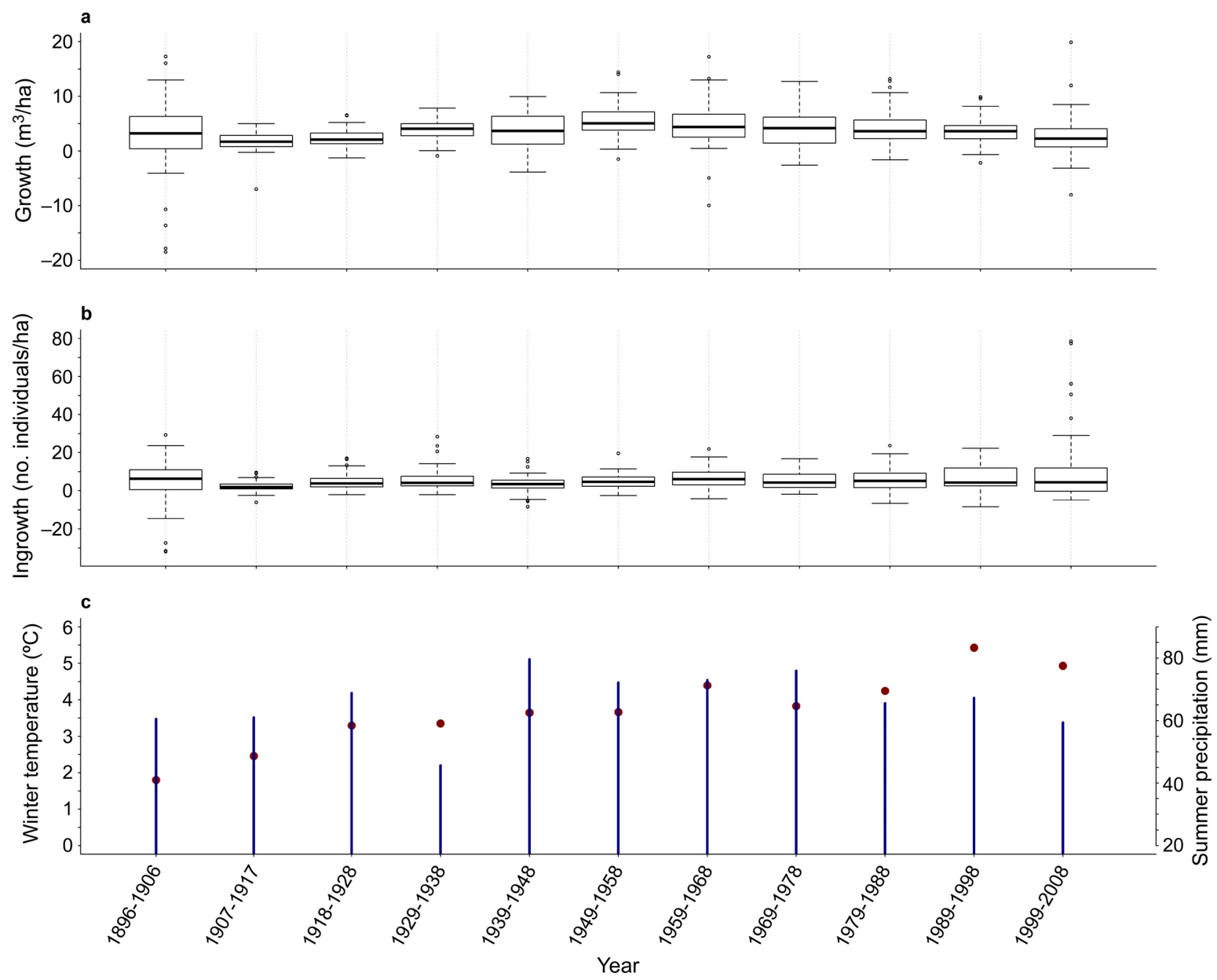

FIG. 2. (a) Growth expressed as changes in stand volume and (b) ingrowth trends of Scots pine during the period 1896-2008. For both boxplots, the mid solid line indicates the median, whereas lower and upper edges indicate the first and third quartile. The whiskers represent maximum and minimum values and the points refer to the outliers. (c) Seasonal climatic patterns shown for decadal periods: winter temperatures (red points) and summer precipitation (blue bars). 
Analogously, $N_{2}$ is the stand density at the time $t, N_{1}$ is the stand density at the time $t-10$, and $N_{t}$ is the harvested stand density in the decade. The data to calculate growth $(G)$ and ingrowth $(I)$ were available for the following periods: 1896-1906, 1907-1917, 1918-1928, 1929-1938, 1939-1948, 1949-1958, 1959-1968, 19691978, 1979-1988, 1989-1998, and 1999-2008.

\section{Climate data}

We obtained monthly climatic data (mean temperature and total precipitation) for the 1901-2008 period from the $0.5^{\circ}$ gridded Climate Research Unit TS3.1 database (Harris et al. 2014), which provides homogenized and quality-controlled climate data. We used the coordinates $40^{\circ} 30^{\prime}-41^{\circ} 00^{\prime} \mathrm{N}, 3^{\circ} 30^{\prime}-4^{\circ} 00^{\prime} \mathrm{W}$ to represent the study area. Data for the 1896-1900 period were obtained from the Madrid-Retiro station $\left(40^{\circ} 24^{\prime} 42^{\prime \prime} \mathrm{N}\right.$, $3^{\circ} 40^{\prime} 41^{\prime \prime} \mathrm{W}, 667 \mathrm{~m}$ a.s.1.) and corrected to represent mid-elevation sites $(1650 \mathrm{~m})$. We calculated decadal values for seasonal climatic data by averaging annual data of winter temperature (hereafter WiTemp) and summer precipitation.

Water availability during the summer season is mainly compromised in the Mediterranean region by reduced rainfall (García-Ruiz et al. 2011). To estimate the effect of summer drought intensity, we used the Standardized Precipitation Index for the summer months (hereafter SuSPI), a widely used index calculated as the number of standard deviations above or below the long-term precipitation over a time period (McKee et al. 1993). We calculated the September 3-month SPI values, i.e., the September SPI for drought accumulated up to 3 months before. To test the robustness against other drought indices, we additionally calculated the Standardized Precipitation-Evapotranspiration Index (SPEI, VicenteSerrano et al. 2010) for September 6-month time scales (hereafter SPEI6).

The climate in the study area shows rising winter temperatures $(P<0.001)$ in the 20th century, as well as increasing summer drought severity is observed toward the end of the study period (Fig. 2c). The driest periods were the 1910s, 1930s, 1980s, 1990s, and 2000s.

\section{Data analyses}

We fitted linear mixed-effects models to evaluate forest growth and forest ingrowth responses to changes in climate and management. The models had the following form

$$
\begin{gathered}
\text { Growth } \sim V_{1} \cdot \text { SuSPI }+ \text { Altitude } \cdot \text { WiTemp }+(1 \mid \text { ID }) \\
\text { Ingrowth } \sim V_{1} \cdot \text { SuSPI }+ \text { Altitude }+(1 \mid \text { ID })
\end{gathered}
$$

where (1|ID) referred to a random intercept on the grouping factor site ID, and the fixed effects were previous stand volume $\left(V_{1}\right)$, SuSPI, and their interaction, which reflects our main hypothesis that changes in stand volume may modify drought sensitivity; and altitude, WiTemp, and their interaction, in order to test the effect of warming winter along the elevation gradient. All continuous predictor variables were standardized (i.e., the mean was subtracted from the variable, and the resulting value was divided by the variable's standard deviation). The standardization improves the interpretability of effect sizes and interactions. Residuals of the models were checked for normality and homoscedasticity. As the initial model showed heavier tails than expected under a normal distribution, we applied power transformations on the response variables (see Appendix S2). The percentage of variance explained by fixed $\left(R^{2} f\right)$ and random effects $\left(R^{2} r\right)$ of the best model were calculated using the method of Nakagawa and Schielzeth (2013). Since the random effect variance for growth model was relatively small, we tested if random effect variances were significantly different from zero, using a simulated likelihood ratio tests (see Appendix S2). Additionally, we fitted a larger model including SPEI6 and ran a global model selection.

All statistical analyses were performed using the $\mathrm{R}$ statistical software (R Development Core Team 2015). We fitted linear mixed-effects models using the lme4 package (Bates et al. 2015) and calculated $P$ values with the package lmerTest (Kuznetsova et al. 2015).

\section{Results}

\section{Forest productivity responses to climate and management}

Across the entire data set, growth ranged between 0 and $10 \mathrm{~m}^{3} / \mathrm{ha}$, while ingrowth varied between 0 and 17 individuals/ha along the 20th century (considering 95\% quartiles). The two response variables were moderately strongly correlated $(0.54)$. There was no clear trend in growth values along the entire century, but growth tended to decrease in the drier decades, for example the 2000s (Fig. 2).

The mixed models identified a significant positive effect of WiTemp and a significant negative effect of altitude and $V_{1}$ on forest growth (Table 1). The interaction between WiTemp and altitude showed a significant negative effect, meaning that the positive effect of warmer winters on Scots pine growth is stronger at lower altitudinal levels. The interaction between SuSPI and $V_{1}$ was significant and positive, meaning that, under drier summer conditions, Scots pines reacted with lower growth values when stand volume was higher. The percentage of growth variance explained by the fixed effects was $10 \%$ (marginal pseudo- $R^{2}$ ). Random effect variance was very small, meaning that the proportion of variance explained was the same with and without random terms (conditional pseudo- $R^{2}$ ). The result of simulated likelihood ratio tests showed no evidence for a significant non-zero random effect of plot on growth $(P=0.402)$. 
TABle 1. Main statistics of the linear mixed-effects models fitted to explain changes in growth and ingrowth of the Scots pine forest.

\begin{tabular}{|c|c|c|c|c|c|c|}
\hline \multirow[b]{2}{*}{ Response variables and parameters } & \multicolumn{3}{|c|}{ Fixed effects } & \multicolumn{3}{|c|}{ Random effects } \\
\hline & Estimates & SE & $P$ & Group intercept & Variance & SD \\
\hline Growth & & & & ID & 0.001 & 0.001 \\
\hline Intercept & 3.576 & 0.044 & $<0.001$ & & & \\
\hline$V_{1}$ & -0.132 & 0.046 & 0.005 & & & \\
\hline SuSPI & 0.044 & 0.045 & 0.334 & & & \\
\hline WiTemp & 0.155 & 0.046 & $<0.001$ & & & \\
\hline Altitude & -0.228 & 0.045 & $<0.001$ & & & \\
\hline$V_{1}:$ SuSPI & 0.119 & 0.055 & 0.030 & & & \\
\hline WiTemp: Altitude & -0.166 & 0.044 & $<0.001$ & & & \\
\hline Ingrowth & & & & ID & 0.001 & 0.030 \\
\hline Intercept & 1.411 & 0.007 & $<0.001$ & & & \\
\hline$V_{1}$ & -0.079 & 0.006 & $<0.001$ & & & \\
\hline SuSPI & -0.005 & 0.006 & 0.381 & & & \\
\hline WiTemp & 0.039 & 0.006 & $<0.001$ & & & \\
\hline Altitude & -0.033 & 0.007 & $<0.001$ & & & \\
\hline$V_{1}:$ SuSPI & 0.021 & 0.007 & 0.002 & & & \\
\hline WiTemp:Altitude & -0.020 & 0.005 & $<0.001$ & & & \\
\hline
\end{tabular}

Notes: Variables were standardized, so effect sizes are directly comparable. Variable abbreviations are $V_{1}$, stand volume; SuSPI, summer Standardized Precipitation Index; WiTemp, winter temperature; SD, standard deviation; ID, site.

For forest ingrowth, we again found a significant positive effect of WiTemp and a negative effect of altitude and $V_{1}$ (Table 1). The interaction between WiTemp and altitude also had a significant negative effect, revealing that winter temperature may favor Scots pine ingrowth strongly at the lower elevations. The interaction between SuSPI and $V_{1}$ was positively significant and pointed to exacerbated adverse effects of summer drought on ingrowth under increased stand volume. The percentage of ingrowth variance explained by the fixed effects was $30 \%$ (marginal pseudo- $R^{2}$ ), while the proportion of variance explained by both the fixed and the random terms was $34 \%$ (conditional pseudo- $R^{2}$ ). The simulated likelihood ratio tests showed significant support for a non-zero random effect variance of plot on ingrowth $(P=0.012)$.

We checked the residual distribution overall, against the predicted value, and against all predictors. Although there were still some slight deviations from normality after the transformation (indicated by a significant Shapiro-Wilk test on the overall residual distribution; $P=0.01325$ for growth model and $P=0.03437$ for ingrowth model), Q-Q plots and residual patterns indicated an overall good fit of the linear mixed models.

Looking at the correlation (see Appendix S2), WiTemp was only weakly correlated to SuSPI, but strongly correlated to spring and summer temperature, as well as moderately strong to SPEI6. Moreover, SPEI6 and SuSPI were moderately strongly correlated. We additionally tested if the models would be improved by including a predictor related to water balance (SPEI6). However, SPEI6 was neither significant in the full model, nor selected over SuSPI in a global $\mathrm{AIC}_{\mathrm{c}}$-based model selection.

\section{Effect of winter temperature along the altitudinal gradient}

Our results show that warming winter benefits Scots pine forests more strongly at lower elevations, for both growth and ingrowth (interactions between WiTemp and altitude, Table 1). This is visually depicted in Fig. 3a, b, which displays the effect of increasing winter temperature depending for different altitudes.

\section{Effect of management legacies on drought impacts}

Our results show that stand structure, and thus management, does modify drought responses (interactions between $V_{1}$ and SuSPI, Table 1). For both growth and ingrowth, higher stand volume is particularly harmful under summer drought conditions. To show the quantitative result of this relationship, we used the fitted models to calculate the effects of increasing stand volume depending on SuSPI (Fig. 3c, d). The results show that stand volume (across its considered range) is nearly inconsequential when water availability is high. Even stand volume may favor Scots pine growth if there is no water limitation. Under drought conditions, however, increasing stand volume markedly reduces forest growth and ingrowth.

\section{Discussion}

In this study, we used a century-long historical data set on forest productivity across an altitudinal gradient in a continental Mediterranean forest to evaluate the response of forest growth and ingrowth to climate and management legacy effects. Our main findings are that warmer winter temperature impacted positively on Scots 

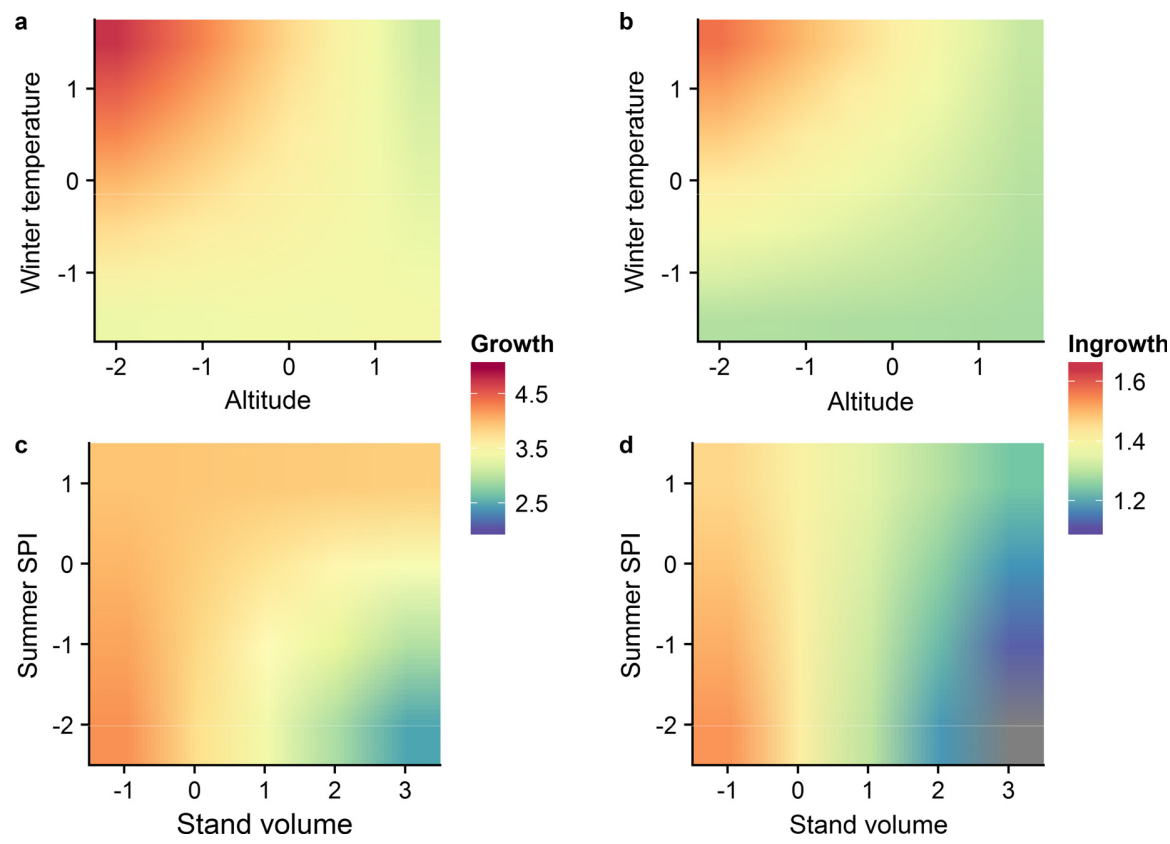

FIG. 3. Expected growth and ingrowth of the Scots pine forest as a function of (a, b) winter temperature (WiTemp) and altitude and of $(\mathrm{c}, \mathrm{d})$ stand volume $\left(V_{1}\right)$ and summer Standardized Precipitation Index (SuSPI). Note that parameters are standardized and response variables (growth and ingrowth) are shown as transformed values. Gradient scale is set from cold (low) to warm (high) colors.

pine forest productivity, more strongly so at lower elevation; that summer drought negatively affected forest productivity; and that drought effects are reduced by lower stand volume, suggesting that management can ameliorate drought impacts.

It was reported before that rising winter temperatures boosts Scots pine growth and ingrowth, possibly due to extending the growing season (Tardif et al. 2003, Camarero et al. 2010). This is line with recent studies suggesting that warming may enhance growth rates when water shortage does not override the temperature effects (Scholze et al. 2006, Martínez-Vilalta et al. 2008, BenitoGarzón et al. 2013, Ruiz-Benito et al. 2014). An increase of temperatures has been observed in Mediterranean mountains during the second half of the 20th century (García-Ruiz et al. 2011), affecting growth patterns of Scots pine. Particularly, young trees exhibited a stronger positive response to increases in temperature than older trees (Gómez-Aparicio et al. 2011), as we observed analyzing the ingrowth model. Higher altitude as such negatively affected forest growth and ingrowth, following the idea that upper distribution limits in mountain pines may be set by tolerance to low temperatures (Ruiz-Benito et al. 2012) as well as by local factors including slope, aspect, wind-exposure or soil conditions (Körner et al. 2016). Contrary to our expectations, this did not translate into higher altitudes benefiting more strongly from warmer temperatures. According to our models, warmer winter benefited Scots pine productivity more strongly at lower elevation. However, it is known that growth-temperature relationships are not linear. The study area is on a northern slope, where episodes of low solar radiation are common. Therefore, growth response to warming at higher altitudes may be moderated since stands grow overall less. A plausible physiological explanation regards that rising temperature could advance phenological development (Walther et al. 2002, Parmesan and Yohe 2003) and increase vulnerability to frost damage of plant tissues due to late frosts (Hänninen 1991, Morin et al. 2007). Moreover, it is also possible that the observed interaction between altitude and winter temperature is spurious, meaning that it does not directly arise through causal interactions of winter temperature with altitude, but rather from other environmental variables that happen to correlate with winter temperature (frost incidence) or with altitude $\left(\mathrm{CO}_{2}, \mathrm{~N}\right.$-deposition).

Our result that summer drought has a strong negative impact on forest productivity, and that this impact is mediated by forest structure agree with previous studies at tree level (Gómez-Aparicio et al. 2011, Vila-Cabrera et al. 2011, Rigling et al. 2013, Sánchez-Salguero et al. $2015 b$ ). The theory behind this observation is that, although stand volume may sometimes positively affect forest productivity due to higher regeneration and seedling germination (Harms et al. 1994, Reyes-Hernández and Comeau 2015), it generally increases competition (Hille Ris Lambers et al. 2002). Apart from general effects on forest dynamics through changes of light and space availability (Callaway and Walker 1997), strong competition will exacerbate water shortage and therefore influence the vulnerability of forest ecosystems to drought events (McDowell et al. 2008, Zhang et al. 
2015). This motivates the idea that negative effect of drought may be mitigated to some extent by stand management, emphasizing the potential of adaptation measure to reduce the effects of climate change (Millar et al. 2007, Vayreda et al. 2012). Our stand-level findings agree with recent studies affirming that a reduction of competition may enhance forest growth in response to episodic droughts (Linares et al. 2010, Martín-Benito et al. 2010, Chmura et al. 2011, Bottero et al. 2017). Although Sohn et al. (2016) suggest that only strong and frequent thinning interventions will yield substantial benefits, our results suggest that shelterwood as well is effective for reducing competition, presumably because this allows keeping the balance between the capacity of young trees to absorb the radiation and the protector effect given by adult trees.

Our analysis used a fixed hypothesis, with predictors selected based on our ecological understanding of the system, and the idea that Scots pine forests in Spain are mainly affected by rainfall decreases and mean temperature increases (Gutierrez 1989). As precipitation is considered more critical than temperatures in limiting tree growth in the summer season, we selected winter temperature and summer precipitation as the two climatic variables that best respond a priori to our ecological question. However, a range of other climate variables has been used in the literature. Apart from winter temperature (Camarero et al. 2015a, Sánchez-Salguero et al. $2015 a$ ), effects were found for winter-spring temperatures (Herrero et al. 2013, Martín-Benito et al. 2013), summer temperatures (Gea-Izquierdo et al. 2014), rainfall during the growing season (Bogino et al. 2009, Sánchez-Salguero et al. 2016), water balance (P-PET) during summer and the growing season (Sánchez-Salguero et al. 2015a), or the 3-month scale SPEI for summer (Martín-Benito et al. 2013). The correlation structure of the environmental data (see Appendix S2) shows three blocks of climate predictors: temperature, precipitation, and water balance predictors such as SPEI and P-PET. While temperature and precipitation are reasonably independent, water balance predictors correlate with both temperature and precipitation, as one would expect. To test if considering water balance would improve the model, we ran additional tests including SPEI6, which was more uncorrelated with SuSPI. The results suggest that WiTemp and SuSPI are better predictors for growth and ingrowth that SPEI6, defending our initial hypothesis.

One limitation of our study toward the goal of understanding how forest dynamics will be affected by climate change is the lack of mortality data in the historical records used for this study. Another limitation is the aggregated climatic analysis, dictated by the decadal resolution of the data set, which we attribute as the cause for the relatively low amount of growth variance explained by climate. Growth is likely influenced not only by decadal means, but also by yearly climatic variability including climate extremes (Coumou and Rahmstorf 2012). Nevertheless, our analysis shows that there is information in this data, evidenced by significant effects of climate and competition, and historical data such as used in this study presents a unique opportunity to complement other data types with their own limitations. Thus, there is a great opportunity for forestry science digitizing more of the many long-term data sets that still reside on paper in the archives of forestry services. In the future, such data could also be combined with other data sources, for example dendrochronological data on yearly radial tree growth, to allow a more detailed analysis of the variability in growth and ingrowth processes.

\section{Conclusions}

Our study confirmed the expectation that warmer winter temperatures favor forest growth and ingrowth of Scots pine populations, while water shortages and droughts limits the same processes. We found significant evidences that altitude modulated the effect of winter temperature, albeit in a somewhat unexpected way: the positive effects of warmer winters were stronger in low altitudes than in high altitudes. We also found strong significant evidence for the fact that water limitation depended on stand volume. It is therefore possible to adapt to increasing drought propensity by stand management.

Our study is one of the first attempts to examine the role of climate and management legacies on productivity at a landscape scale in a rear edge forest. Our results highlight the danger of climate change for these forests, but also point to potential adaptation and mitigation measures. The presented findings are also relevant to better understand what pressures act on rear-edge tree populations and managed forests worldwide, with the goal of preserving their functioning in the future.

\section{ACKNOWLEDGMENTS}

We are grateful to Maria Bragado and José Ignacio Quintanilla (Servicio Territorial de Medioambiente de Segovia, Spain) for their support with the historical archives and for helping with the data acquisition. We also thank two anonymous reviewers for their useful comments in an earlier version of the manuscript. L. Marqués acknowledges funding from EU COST ACTION FP1304 PROFOUND for a Short Term Scientific Mission at the Department of Biometry and Environmental System Analysis (Albert-Ludwings-Universität, Freiburg), and thanks all members of the department for their helpful advices. L. Marqués is supported by a FPI grant from the University of Alcala. J. Madrigal is funded by a postdoctoral grant from the University of Alcala. We acknowledge funding provided by projects VULPINECLIM (Spanish Ministry of Economy and Competitiveness, MINECO, Spain; CGL-2013-44553-R) and FUNDIVER (MINECO, Spain; CGL2015-69186-C2-1-R and CGL2015-69186-C2-2-R projects).

\section{Literature Cited}

Allen, C. D., et al. 2010. A global overview of drought and heat-induced tree mortality reveals emerging climate change risks for forests. Forest Ecology and Management 259:660-684. Anderegg, W. R. L., J. M. Kane, and L. D. L. Anderegg. 2013. Consequences of widespread tree mortality triggered by 
drought and temperature stress. Nature Climate Change 3:30-36.

Anderegg, W. R. L., et al. 2015. Pervasive drought legacies in forest ecosystems and their implications for carbon cycle models. Science 349:528-532.

Barbero, M., R. Loisel, P. Quézel, D. M. Richardson, and F. Romane. 1998. Pines of the Mediterranean basin. Pages 153170 in D. M. Richardson, editor. Ecology and biogeography of Pinus. Cambridge University Press, Cambridge.

Bates, D., M. Mächler, B. Bolker, and S. Walker. 2015. Fitting linear mixed-effects models using lme4. Journal of Statistical Software 67:1-48.

Benavides, R., A. Escudero, L. Coll, P. Ferrandis, R. Ogaya, F. Gouriveau, J. Peñuelas, and F. Valladares. 2016. Recruitment patterns of four tree species along elevation gradients in Mediterranean mountains: not only climate matters. Forest Ecology and Management 360:287-296.

Benito-Garzón, M., P. Ruiz-Benito, and M. A. Zavala. 2013. Interspecific differences in tree growth and mortality responses to environmental drivers determine potential species distributional limits in Iberian forests. Global Ecology and Biogeography 22:1141-1151.

Binkley, D., J. L. Stape, and M. G. Ryan. 2004. Thinking about efficiency of resource use in forests. Forest Ecology and Management 193:5-16.

Bogino, S., M. J. Fernández Nieto, and F. Bravo. 2009. Climate effect on radial growth of Pinus sylvestris at its southern and western distribution limits. Silva Fennica 43:609-623.

Boisvenue, C., and S. W. Running. 2006. Impacts of climate change on natural forest productivity-evidence since the middle of the 20th century. Global Change Biology 12:862-882.

Bottero, A., A. W. D'Amato, B. J. Palik, J. B. Bradford, S. Fraver, M. A. Battaglia, and L. A. Asherin. 2017. Densitydependent vulnerability of forest ecosystems to drought. Journal of Applied Ecology. https://doi.org/10.1111/1365-2664. 12847.

Bowman, D. M. J. S., R. J. W. Brienen, E. Gloor, O. L. Phillips, and L. D. Prior. 2013. Detecting trends in tree growth: not so simple. Trends in Plant Science 18:11-17.

Callaway, R. M., and L. R. Walker. 1997. Competition and facilitation: a synthetic approach to interactions in plant communities. Journal of Ecology 78:1958-1965.

Camarero, J. J., J. M. Olano, and A. Parras. 2010. Plastic bimodal xylogenesis in conifers from continental Mediterranean climates. New Phytologist 185:471-480.

Camarero, J. J., C. Bigler, J. C. Linares, and E. Gil-Pelegrín. 2011. Synergistic effects of past historical logging and drought on the decline of Pyrenean silver fir forests. Forest Ecology and Management 262:759-769.

Camarero, J., A. Gazol, S. Sancho-Benages, and G. SangüesaBarreda. 2015a. Know your limits? Climate extremes impact the range of Scots pine in unexpected places. Annals of Botany 116:917-927.

Camarero, J., A. Gazol, G. Sangüesa-Barreda, J. Oliva, and S. M. Vicente-Serrano. 2015b. To die or not to die: early warnings of tree dieback in response to a severe drought. Journal of Ecology 103:44-57.

Candel-Pérez, D., J. C. Linares, B. Viñegla, and M. E. LucasBorja. 2012. Assessing climate-growth relationships under contrasting stands of co-occurring Iberian pines along an altitudinal gradient. Forest Ecology and Management 274:48-57.

Chmura, D. J., P. D. Anderson, G. T. Howe, C. A. Harrington, J. E. Halofsky, D. L. Peterson, D. C. Shaw, and J. Brad St. Clair. 2011. Forest responses to climate change in the northwestern United States: ecophysiological foundations for adaptive management. Forest Ecology and Management 261:1121-1142.
Churkina, G., and S. W. Running. 1998. Contrasting climatic controls on the estimated productivity of global terrestrial biomes. Ecosystems 1:206-215.

Coumou, D., and S. Rahmstorf. 2012. A decade of weather extremes. Nature Climate Change 2:491-496.

Croitoru, L., and M. Merlo. 2005. Mediterranean forest values. Valuing mediterranean forests: towards total economic value. Pages 37-68 in M. Merlo, and L. Croitoru, editors. Valuing Mediterranean forests: towards total economic value. CABI Publication, Wallingford, UK.

Eilmann, B., and A. Rigling. 2012. Tree-growth analyses to estimate tree species' drought tolerance. Tree Physiology 32: 178-187.

Fischlin, A., G. F. Midgley, J. T. Price, R. Leemans, B. Gopal, C. Turley, M. D. A. Rounsevell, O. P. Dube, J. Tarazona, and A. A. Velichko. 2007. Ecosystems, their properties, goods, and services. Chapter 4. Pages 211-272 in M. L. Parry, O. F. Canziani, J. P. Palutikof, P. J. van der Linden and C. E. Hanson, editors. Climate change 2007: impacts adaptation and vulnerability. Contribution of working group II to the fourth assessment report of the intergovernmental panel on climate change. Cambridge University Press, Cambridge, UK.

Frelich, L. 2002. Forest dynamics and disturbance regimes: studies from temperate evergreen-deciduous forests. Cambridge University Press, Cambridge, UK.

Galiano, L., J. Martínez-Vilalta, and F. Lloret. 2010. Droughtinduced multifactor decline of Scots pine in the Pyrenees and potential vegetation change by the expansion of co-occurring oak species. Ecosystems 13:978-991.

Galván, J. D., J. J. Camarero, C. Ginzler, and U. Büntgen. 2014. Spatial diversity of recent trends in Mediterranean tree growth. Environmental Research Letters 9:1-11.

Galván, D. J., U. Büntgen, C. Ginzler, H. Grudd, E. Gutiérrez, I. Labuhn, and J. Julio Camarero. 2015. Drought-induced weakening of growth-temperature associations in high-elevation Iberian pines. Global and Planetary Change 124:95-106.

García-Ruiz, J. M., I. I. López-Moreno, S. M. Vicente-Serrano, T. Lasanta-Martínez, and S. Beguería. 2011. Mediterranean water resources in a global change scenario. Earth-Science Reviews 105:121-139.

Gea-Izquierdo, G., B. Viguera, M. Cabrera, and I. Canellas. 2014. Drought induced decline could portend widespread pine mortality at the xeric ecotone in managed Mediterranean pine-oak woodlands. Forest Ecology and Management 320:70-82.

Giuggiola, A., H. Bugmann, A. Zingg, M. Dobbertin, and A. Rigling. 2013. Reduction of stand density increases drought resistance in xeric Scots pine forests. Forest Ecology and Management 310:827-835.

Gómez-Aparicio, L., R. García-Valdés, P. Ruíz-Benito, and M. A. Zavala. 2011. Disentangling the relative importance of climate, size and competition on tree growth in Iberian forests: implications for forest management under global change. Global Change Biology 17:2400-2414.

Gutierrez, E. 1989. Dendroclimatological study of Pinus sylvestris L. in southern Catalonia (Spain). Tree-Ring Bulletin 49:1-9.

Hampe, A., and R. J. Petit. 2005. Conserving biodiversity under climate change: the rear edge matters. Ecology Letters 8: 461-467.

Hänninen, H. 1991. Does climate warming increase the risk of frost damage in northern trees? Plant Cell Environment $14: 449-454$.

Harms, W. R., D. S. Debell, and C. D. Whitesell. 1994. Stand and tree characteristics and stockability in Pinus taeda plantations in Hawaii and South Carolina. Canadian Journal of Forest Research 24:511-521. 
Harris, I., P. D. Jones, T. J. Osborn, and D. H. Lister. 2014. Updated high-resolution grids of monthly climatic observations. International Journal of Climatology 34:623-42.

Herguido, E., E. Granda, R. Benavides, A. I. García-Cervigón, J. J. Camarero, and F. Valladares. 2016. Contrasting growth and mortality responses to climate warming of two pine species in a continental Mediterranean ecosystem. Forest Ecology and Management 363:149-158.

Herrero, A., A. Rigling, and R. Zamora. 2013. Varying climate sensitivity at the dry distribution edge of Pinus sylvestris and P. nigra. Forest Ecology and Management 308:50-61.

Hille Ris Lambers, J., J. S. Clark, and B. Beckage. 2002. Density-dependent mortality and the latitudinal gradient in species diversity. Nature 417:732-735.

IPCC. 2014. Climate Change 2014: Synthesis Report. Contribution of Working Groups I, II and III to the Fifth Assessment Report of the Intergovernmental Panel on Climate Change [Core Writing Team, R.K. Pachauri and L.A. Meyer (eds.)]. IPCC, Geneva, Switzerland, $151 \mathrm{pp}$.

Keenan, R. J. 2012. Adaptation of forests and forest management to climate change: an editorial. Forests 3:75-82.

Klein, R. J. T., S. Huq, F. Denton, T. E. Downing, R. G. Richels, J. B. Robinson, and F. L. Toth. 2007. Inter-relationships between adaptation and mitigation. Chapter 18. Pages 745-777 in M. L. Parry, O. F. Canziani, J. P. Palutikof, P. J. van der Linden and C. E. Hanson, editors. Climate change 2007: impacts, adaptation and vulnerability. Contribution of working group II to the fourth assessment report of the intergovernmental panel on climate change. Cambridge University Press, Cambridge, UK.

Körner, C. 2015. Paradigm shift in plant growth control. Current Opinion in Plant Biology 25:107-114.

Körner, C., D. Basler, G. Hoch, C. Kollas, A. Lenz, C. F. Randin, Y. Vitasse, and N. E. Zimmermann. 2016. Where, why and how? Explaining the low temperature range limits of temperate tree species. Journal of Ecology 104:1076-1088.

Kottek, M., J. Grieser, C. Beck, B. Rudolf, and F. Rubel. 2006. World map of the Köppen-Geiger climate classification updated. Meteorologische Zeitschrift 15:259-263.

Kuznetsova, A., P. B. Brockhoff, and R. H. B. Christensen. 2013. ImerTest: Tests for random and fixed effects for linear mixed effect models (lmer objects of lme4 package). R package version, 2(6).

Linares, J. C., J. J. Camarero, and J. A. Carreira. 2010. Competition modulates the adaptation capacity of forests to climatic stress: insights from recent growth decline and death in relict stands of the Mediterranean fir Abies pinsapo. Journal of Ecology 98:592-603.

Madrigal-González, J., and M. A. Zavala. 2014. Competition and tree age modulated last century pine growth responses to high frequency of dry years in a water limited forest ecosystem. Agricultural and Forest Meteorology 192-193:18-26.

Madrigal-González, J., S. Hantson, C. Yue, B. Poulter, P. Ciais, and M. A. Zavala. 2015. Long-term wood production in water-limited forests: evaluating potential $\mathrm{CO}_{2}$ fertilization along with historical confounding factors. Ecosystems 18: 1043-1055.

Magruder, M., S. Chhin, B. Palik, and J. B. Bradford. 2013. Thinning increases climatic resilience of red pine. Canadian Journal of Forest Research 43:878-889.

Marqués, L., J. J. Camarero, A. Gazol, and M. A. Zavala. 2016. Drought impacts on tree growth of two pine species along an altitudinal gradient and their use as early-warning signals of potential shifts in tree species distributions. Forest Ecology and Management 381:157-167.

Martín-Benito, D., M. Del Río, I. Heinrich, G. Helle, and I. Cañellas. 2010. Response of climate-growth relationships and water use efficiency to thinning in a Pinus nigra afforestation. Forest Ecology and Management 259:967-975.

Martín-Benito, D., H. Beeckman, and I. Cañellas. 2013. Influence of drought on tree rings and tracheid features of Pinus nigra and Pinus sylvestris in a mesic Mediterranean forest. European Journal of Forest Research 132:33-45.

Martínez-Vilalta, J., and J. Piñol. 2002. Drought-induced mortality and hydraulic architecture in pine populations of the NE Iberian Peninsula. Forest Ecology and Management 161:247-256

Martínez-Vilalta, J., B. C. López, N. Adell, L. Badiella, and M. Ninyerola. 2008. Twentieth century increase of Scots pine radial growth in NE Spain shows strong climate interactions. Global Change Biology 14:2868-2881.

McDowell, N., et al. 2008. Mechanisms of plant survival and mortality during drought: Why do some plants survive while others succumb to drought? New Phytologist 178:719-739.

McKee, T. B. N., J. Doesken, and J. Kleist. 1993: The relationship of drought frequency and duration to time scales. Pages 179-184 in Eighth Conference On Applied Climatology. American Meteorological Society, Anaheim, California,.

Menzel, A., and P. Fabian. 1999. Growing season extended in Europe. Nature 397:659.

Millar, C. I., N. L. Stephenson, and S. L. Stephens. 2007. Climate change and forest of the future: managing in the face of uncertanity. Ecological Applications 17:2145-2151.

Morin, X., T. Améglio, R. Ahas, C. Kurz-Besson, V. Lanta, F. Lebourgeois, F. Miglietta, and I. Chuine. 2007. Variation in cold hardiness and carbohydrate concentration from dormancy induction to bud burst among provenances of three European oak species. Tree Physiology 27:817-825.

Nabuurs, G.-J., M. Lindner, P. J. Verkerk, K. Gunia, P. Deda, R. Michalak, and G. Grassi. 2013. First signs of carbon sink saturation in European forest biomass. Nature Climate Change 3:792-796.

Nakagawa, S., and H. Schielzeth. 2013. A general and simple method for obtaining R2 from generalized linear mixedeffects models. Methods in Ecology and Evolution 4:133-142.

Nogués Bravo, D., M. B. Araújo, T. Lasanta, and J. I. López Moreno. 2008. Climate change in Mediterranean mountains during the 21st century. Ambio 37:280-285.

Pan, Y., et al. 2011. A large and persistent carbon sink in the world's forests. Science 333:988-993.

Parmesan, C., and G. Yohe. 2003. A globally coherent fingerprint of climate change impacts across natural systems. Nature 421:37-42.

Peñuelas, J., and I. Filella. 2001. Phenology. Responses to a warming world. Science 294:793-795.

Peñuelas, J., J. G. Canadell, and R. Ogaya. 2011. Increased water-use efficiency during the 20th century did not translate into enhanced tree growth. Global Ecology and Biogeography 20:597-608.

Pretzsch, H. 2006. Species-specific allometric scaling under selfthinning: evidence from long-term plots in forest stands. Oecologia 146:572-583.

Pretzsch, H. 2009. Forest dynamics, growth and yield from measurement to model. Pages 423-491 in H. Pretzsch, editor. Forest dynamics, growth and yield. Springer, Heidelberg, Germany

Pretzsch, H., and P. Biber. 2005. A re-evaluation of Reineke's rule and stand density index. Forest Science 605:304-320.

Pretzsch, H., P. Biber, G. Schütze, E. Uhl, and T. Rötzer. 2014. Forest stand growth dynamics in Central Europe have accelerated since 1870. Nature Communications 5:4967.

R Core Team. 2015. R: a language and environment for statistical computing. R Foundation for Statistical Computing, Vienna, Austria. http://www.R-project.org/ 
Rees, M., M. Rees, R. Condit, M. Crawley, S. Pacala, and D. Tilman. 2001. Long-term studies of vegetation dynamics. Science 293:650-655.

Reyes-Hernández, V. J., and P. G. Comeau. 2015. The influence of stocking and stand composition on productivity of boreal trembling aspen-white spruce stands. Forest 6:4573-4587.

Rigling, A., et al. 2013. Driving factors of a vegetation shift from Scots pine to pubescent oak in dry Alpine forests. Global Change Biology 19:229-240.

Ruiz-Benito, P., L. Gómez-Aparicio, and M. A. Zavala. 2012. Large-scale assessment of regeneration and diversity in Mediterranean planted pine forests along ecological gradients. Diversity and Distributions 18:1092-1106.

Ruiz-Benito, P., E. R. Lines, L. Gómez-Aparicio, M. A. Zavala, and D. A. Coomes. 2013. Patterns and drivers of tree mortality in Iberian forests: climatic effects are modified by competition. PLoS ONE 8:1-10.

Ruiz-Benito, P., L. Gómez-Aparicio, A. Paquette, C. Messier, J. Kattge, and M. A. Zavala. 2014. Diversity increases carbon storage and tree productivity in Spanish forests. Global Ecology and Biogeography 23:311-322.

Sánchez-Salguero, R., R. M. Navarro-Cerrillo, T. W. Swetnam, and M. A. Zavala. 2012. Is drought the main decline factor at the rear edge of Europe? The case of southern Iberian pine plantations. Forest Ecology and Management 271:158-169.

Sánchez-Salguero, R., et al. 2015a. What drives growth of Scots pine in continental Mediterranean climates: drought, low temperatures or both? Agricultural and Forest Meteorology 206:151-162.

Sánchez-Salguero, R., et al. 2015b. Disentangling the effects of competition and climate on individual tree growth: a retrospective and dynamic approach in Scots pine. Forest Ecology and Management 358:12-25.

Sánchez-Salguero, R., J. J. Camarero, E. Gutiérrez, F. González Rouco, A. Gazol, G. Sangüesa-Barreda, and K. Seftigen. 2016. Assessing forest vulnerability to climate warming using a process-based model of tree growth: bad prospects for rearedges. Global Change Biology 23:2705-2719.

Scholze, M., W. Knorr, N. W. Arnell, and I. C. Prentice. 2006. A climate-change risk analysis for world ecosystems. Proceedings of the National Academy of Sciences USA 103:13116-13120.
Schröter, D., et al. 2005. Ecosystem service supply and vulnerability to global change in Europe. Science 310:1333-1337.

Schulze, E.-D., E. Beck, and K. Müller-Hohenstein. 2005. Plant ecology. Springer Verlag, Berlin.

Smith, D. M., B. C. Larson, M. J. Kelty, and P. M. S. Ashton. 1997. The practice of silviculture: applied forest ecology. John Wiley \& Sons, United States of America.

Sohn, J. A., F. Hartig, M. Kohler, J. Huss, and J. Bauhus. 2016. Heavy and frequent thinning promotes drought adaptation in Pinus sylvestris forests. Ecological Applications 26:2190-2205.

Spiecker, H. 1999. Overview of recent growth trends in European forests. Water, Air, and Soil Pollution 116:33-46.

Tardif, J., J. J. Camarero, M. Ribas, and E. Gutierrez. 2003. Spatiotemporal variability in tree growth in the central Pyrenees: climatic and site influences. Ecological Monographs 73:241-257.

Vayreda, J., J. Martinez-Vilalta, M. Gracia, and J. Retana. 2012. Recent climate changes interact with stand structure and management to determine changes in tree carbon stocks in Spanish forests. Global Change Biology 18:1028-1041.

Vicente-Serrano, S. M., S. Beguería, and J. I. López-Moreno. 2010. A multiscalar drought index sensitive to global warming: the standardized precipitation evapotranspiration index. Journal of Climate 23:1696-1718.

Vicente-Serrano, S. M., et al. 2013. Response of vegetation to drought time-scales across global land biomes. Proceedings of the National Academy of Sciences USA 110:52-57.

Vila-Cabrera, A., J. Martinez-Vilalta, J. Vayreda, and J. Retana. 2011. Structural and climatic determinants of demographic rates of Scots pine forests across the Iberian Peninsula. Ecological Applications 21:1162-1172.

Walther, G.-R., E. Post, P. Convey, A. Menzel, C. Parmesan, T. J. C. Beebee, J. Fromentin, O. Hoegh-Guldberg, and F. Bairlein. 2002. Ecological responses to recent climate change. Nature 416:389-395.

Wullschleger, S. D., T. J. Tschaplinski, and R. J. Norby. 2002. Plant water relations at elevated $\mathrm{CO} 2$ - implications for waterlimited environments. Plant, Cell and Environment 25:319-331.

Zhang, J., S. Huang, and F. He. 2015. Half-century evidence from western Canada shows forest dynamics are primarily driven by competition followed by climate. Proceedings of the National Academy of Sciences USA 112:4009-4014.

\section{SUPPORTING INFORMATION}

Additional supporting information may be found online at: http://onlinelibrary.wiley.com/doi/10.1002/eap.1631/full

\section{Data Availability}

Data associated with this paper describing forest productivity are available by request in person or by mail to: Sr. D. José Ignacio Quintanilla Rubio, Jefe del Servicio Territorial de Medio Ambiente de Segovia, Plaza Reina Doña Juana, 1, 40001, Segovia (Spain). 